\title{
Diagnosis dan Penatalaksanaan Pott's Puffy Tumor dengan Pendekatan Endonasal dan Eksternal
}

Faisal Hamdy, Bestari Jaka Budiman

\begin{abstract}
Abstrak
Pott's puffy tumor adalah abses subperiosteal pada dinding anterior sinus frontal yang terjadi akibat osteomielitis tulang frontal. Pott's Puffy tumor merupakan komplikasi dari sinusitis frontal dan trauma kepala pada bagian frontal. Pott's Puffy tumor memberikan gejala klinis berupa bengkak dan edema pada dahi dan kulit kepala. Penatalaksanaan Pott's puffy tumor bertujuan untuk drainase sinus, membersihkan jaringan tulang yang terinfeksi, dan membersihkan jaringan granulasi. Dilaporkan satu kasus rinosinusitis kronis dengan polip nasi dengan komplikasi Pott's puffy tumor pada seorang wanita berusia 36 tahun. Diagnosis ditegakkan berdasarkan anamnesis, pemeriksaan fisik, nasoendoskopi dan CT scan sinus paranasal. Penatalaksanaan yang dilakukan adalah Bedah Sinus Endoskopi Fungsional (BSEF) untuk drainase sinus frontal dan pendekatan perkutaneus (external approach) untuk membersihkan jaringan dan tulang yang terinfeksi. Pott's puffy tumor merupakan komplikasi rinosinusitis kronis yang sangat jarang terjadi. Penatalaksanaan Pott's puffy tumor dilakukan dengan pendekatan medikamentosa dan bedah untuk drainase sinus frontal dan untuk membersihkan jaringan dan tulang yang terinfeksi.
\end{abstract}

Kata kunci: BSEF, pendekatan eksternal, Pott's puffy tumor, Rinosinusitis kronis

\section{Abstract}

Pott's Puffy tumor is a subperiosteal abscess on the anterior wall of the frontal sinus due to frontal bone osteomyelitis. Pott's puffy tumor is a complication of frontal sinusitis and after head trauma. Pott's Puffy tumor causing swelling and edema over the forehead and scalp. The goal of surgery in Pott's puffy is to drain the sinus, remove infected bone or granulation tissue. It was reported a case of chronic rhinosinusitis with nasal polyp with Pott's puffy tumor in a 36-year-old woman. Diagnosis based on anamnesis, physical examination, nasendoscopy and paranasal sinus CT. The management of this case was functional endoscopic sinus surgery (FESS) for frontal sinus drainage and percutaneous approach for remove infected bone or granulation tissue. Pott's puffy tumor is a very rare complication of chronic rhinosinusitis. The management of Pott's puffy tumor with medicamentosa and surgery for frontal sinus drainage and remove infected bone or granulation tissue.

Keywords: Chronic rhinosinusitis, external approach, FESS, Pott's puffy tumor

Affiliasi penulis: Bagian THT-KL Fakultas Kedokteran, Universitas Andalas, Padang, Indonesia

Korespondensi: bestari_budiman@yahoo.co.id

Telp: +6285365677779

\section{PENDAHULUAN}

Pott's puffy tumor adalah abses subperiosteal pada dinding anterior sinus frontal yang terjadi akibat osteomielitis tulang frontal. , 2,3 Pott's puffy tumor tidak hanya diakibatkan karena rinosinusitis pada sinus frontal, tapi juga bisa diakibatkan oleh adanya trauma kepala pada bagian frontal. ${ }^{1,3}$
Pott's puffy tumor lebih sering terjadi pada remaja, dan jarang terjadi pada orang dewasa. Hal ini terjadi karena pada usia remaja, aliran vena diploic meningkat, dengan jaringan ikat longgar di antara sinus frontal dan sumsum tulang yang memungkinkan penyebaran infeksi lebih mudah terjadi. ${ }^{1,3}$

Pott's puffy tumor dapat terjadi bersamaan dengan penyakit penyerta yang lain, seperti diabetes melitus, gagal ginjal kronik dan anemia aplastik. Penyakit penyerta tersebut dapat menyebabkan penurunan daya tahan tubuh sehingga infeksi pada sinus frontal menjadi aktif. ${ }^{3}$ 


\section{Gejala Klinis}

Bengkak yang pucat dan pitting pada kening. Sering terjadi edema signifikan pada jaringan yang terdapat di sekitar abses dan dapat menyebar ke jaringan preseptal orbita. Gejala klinis lainnya yang dapat menyertai berupa sakit kepala, demam, keluar ingus dari hidung, dan nyeri pada sinus frontal. Bila telah terjadi komplikasi ke intrakranial dapat juga menimbulkan gejala meningitis atau ensefalitis. ${ }^{1,4}$

\section{Pemeriksaan Penunjang}

Pemeriksaan CT dengan kontras merupakan modalitas imaging yang paling efektif karena bisa menilai tulang dan jaringan lunak. ${ }^{4,5,6}$ Pemeriksaan CT dapat menilaii sinusitis, erosi tulang, abses subperiosteal, dan perluasan ke intrakranial. Pemeriksaan CT orbita juga diindikasikan bila terdapat selulitis preseptal atau bila visus atau pergerakan bola mata terganggu. Modalitas pilihan lain yang dapat digunakan untuk pemeriksaan penunjang PPT adalah Magnetic Resonance Imaging (MRI). ${ }^{1,4}$

\section{Penatalaksanaan}

Penatalaksanaan PPT dengan terapi antibiotik saja tidak cukup adekuat untuk menyembuhkan penyakit, sehingga dibutuhkan kombinasi drainase dengan pembedahan. Tujuan tindakan pembedahan pada PPT adalah untuk drainase sinus, membersihkan jaringan tulang yang terinfeksi, dan membersihkan jaringan granulasi. ${ }^{2,3}$

Pendekatan pembedahan untuk sinusitis frontal terbagi 2, yaitu pendekatan endonasal dan prosedur eksternal. Pendekatan endonasal dapat berupa etmoidektomi anterior perendoskopik, sinotomi frontal intranasal, rescue procedure sinus frontal, Draf II/III, bedah endoskopik modifikasi Lothrop, dan sinotomi frontal transeptal. Prosedur eksternal dapat berupa trepanasi sinus frontal dan sinotomi eksternal sinus frontal dengan insisi Lynch atau pendekatan flap osteoplastik. ${ }^{7,8}$

\section{KASUS}

Seorang wanita usia 36 tahun datang ke Poliklinik THT-KL RSUP Dr. M. Djamil Padang dengan keluhan utama keluar nanah bercampur darah dari lubang di atas kelopak mata kiri atas sejak 3 bulan sebelum masuk rumah sakit. Sebelumnya pasien mengalami benturan pada kepala di daerah kening 7 bulan sebelum masuk rumah sakit. Pasien kemudian mengeluhkan bengkak di kening yang timbul 4 bulan yang lalu. Pasien sudah kontrol ke dokter spesialis bedah saraf dan dilakukan pemeriksaan $C T$ brain, namun tidak ditemukan kelainan. Bengkak di kening pecah dan mengeluarkan nanah dari lubang di bagian atas kelopak mata kiri atas pasien 3 bulan sebelum masuk rumah sakit. Pasien berobat ke dokter spesialis mata, namun tidak ditemukan kelainan. Pasien juga mengeluhkan hidung tersumbat yang sudah dirasakan sejak 6 tahun yang lalu. Keluhan lainnya yaitu rasa tertelan dahak di tenggorok, penurunan penciuman, rasa berat di wajah, dan sakit kepala hilang timbul.

Pemeriksaan nasoendoskopi kavum nasi kanan didapatkan kavum nasi sempit, tampak massa polip memenuhi kavum nasi, konka inferior sukar dinilai, konka media dan meatus media sukar dinilai, sekret mukoid, septum deviasi tidak ada, dan ditemukan post nasal drip di nasofaring. Kavum nasi kiri sempit, tampak massa polip pada kavum nasi, konka inferior eutrofi, berwarna merah muda, konka media dan meatus media tidak bisa dinilai, sekret mukoid, terdapat septum deviasi dan ditemukan post nasal drip di nasofaring. Pada regio orbita sinistra, tampak fistula di bagian atas palpebra superior kiri. Tampak pus berwarna keputihan keluar dari fistula. Hiperemis tidak ada, nyeri tekan tidak ada (Gambar 1).

Pemeriksaan CT Scan sinus paranasal, kesan pansinusitis dengan gambaran deviasi septum nasi ke kiri dan sugestif Pott's Puffy Tumor dengan skor LundMackay 18 (Gambar 2). Hasil pemeriksaan darah dalam batas normal. Pada pemeriksaan kultur sekret pada kavum nasi dan fistula di regio orbita ditemukan kuman Stafilokokus aureus. 


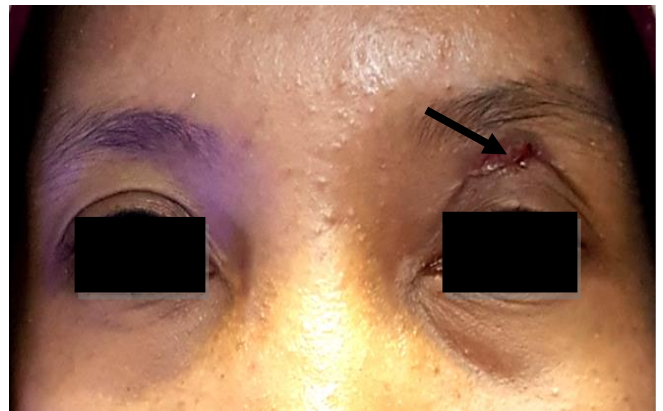

Gambar 1. Pemeriksaan regio orbita kiri. Tampak fistula di bagian atas palpebra superior. Tampak pus berwarna keputihan keluar dari fistula
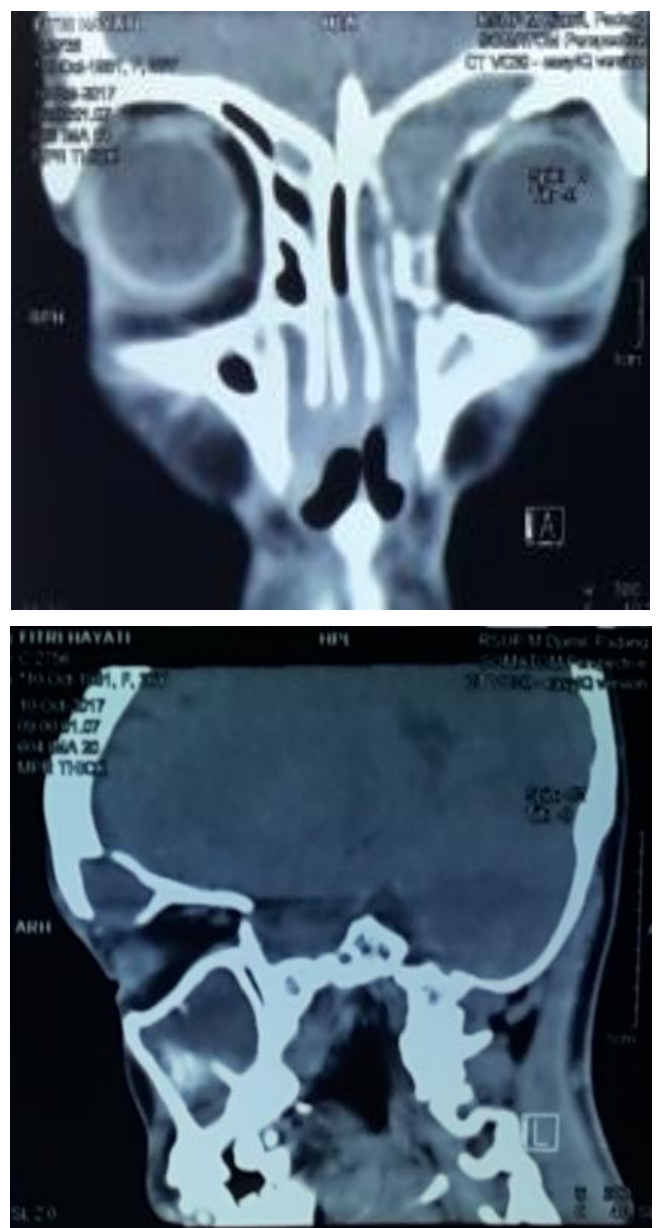

Gambar 2. CT Sinus Paranasal. A. Potongan koronal, tampak erosi pada dinding sinus frontal kiri $\mathbf{B}$. Potongan sagital memperlihatkan dinding sinus frontal yang tidak intak.
Pasien didiagnosis kerja dengan rinosinusitis kronis dengan polip nasi bilateral grade 2 dan Pott's Puffy tumor. Tindakan yang dilakukan adalah BSEF, polipektomi, septoplasti dan debridemant serta kuretase pada fistel frontokutaneus.

Pasca operasi diberikan drip $100 \mathrm{mg}$ tramadol dalam $500 \mathrm{cc} R \mathrm{RL}$, seftriakson $2 \times 1 \mathrm{gr}$ dan deksametason $3 \times 5 \mathrm{mg}$ dan diawasi tanda-tanda vital, tanda-tanda perdarahan, adanya air mata bercampur darah, diberikan diet ML 6 jam post operasi dan kepala diangkat $30^{\circ}$.

Pada hari keempat pasca operasi, keluhan tidak ada, keadaan umum dan tanda vital dalam batas normal. Tampon anterior kemudian dibuka, dan pasien diperbolehkan pulang. Pasien diberi terapi siprofloksasin 2x500mg dan $\mathrm{N}$-asetil sistein 3×200 mg. Pada minggu ke-2 pasca operasi, pasien kontrol kembali ke poliklinik THT-KL. Tidak terdapat keluhan. Pada pemeriksaan nasoendoskopi kavum nasi kanan, kavum nasi lapang, konka inferior eutrofi, warna merah muda, konka media tidak ada, meatus media terbuka, sekret mukoid, krusta ada, septum deviasi tidak ada. Pada kavum nasi kiri, kavum nasi lapang, konka inferior eutrofi, warna merah muda, konka media tidak ada, meatus media terbuka, sekret mukoid, krusta ada, septum deviasi tidak ada Pada regio orbita kiri tampak hematom pada palpebra inferior, tidak ditemukan edem, luka operasi baik dan tidak tampak pus dari luka operasi. Pasien diberi terapi cuci hidung dan eritromisin 2x500 mg.

Pada bulan pertama pasca operasi, pasien sudah tidak memiliki keluhan. Pemeriksaan nasoendoskopi dilakukan, didapatkan kavum nasi kanan dan kiri lapang, konka inferior eutrofi, warna merah muda, konka media tidak ada, meatus media terbuka, secret tidak ada, krusta tidak ada, septum deviasi tidak ada. Tidak ditemukan edem pada regio orbita kiri dan hematom pada palpebra inferior. Luka operasi baik dan tidak terdapat pus (Gambar 3). Pasien diberi terapi cuci hidung. 

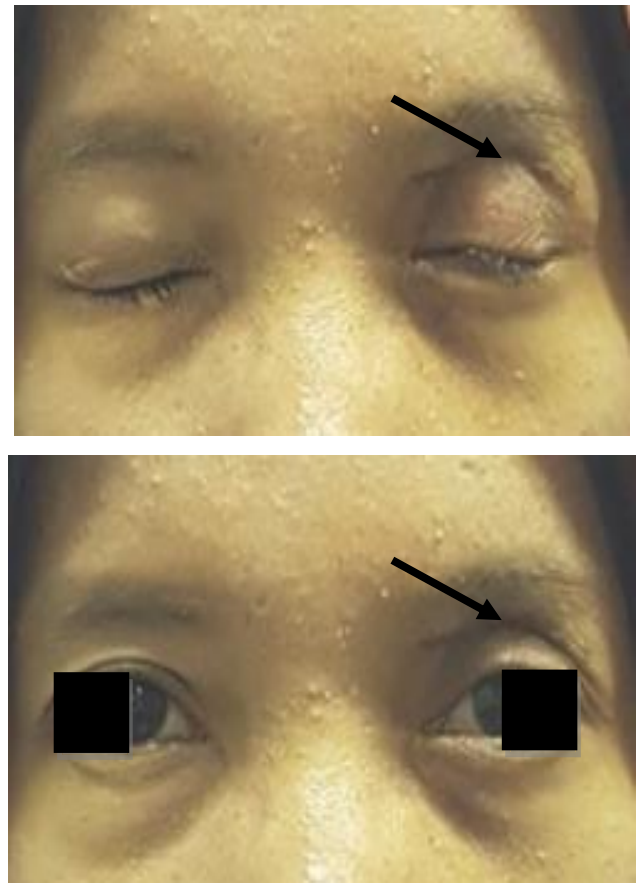

Gambar 4. Pemeriksaan regio orbita kiri pada bulan pertama pasca operasi. Tidak ditemukan edem pada regio orbita kiri dan hematom pada palpebra inferior. Luka operasi baik dan tidak terdapat pus.

\section{PEMBAHASAN}

Kasus Pott's puffy tumor pada dewasa sangat jarang terjadi. Pott's puffy tumor pada dewasa biasanya memiliki penyakit dasar yang mengikutinya seperti diabetes, gagal ginjal kronis, anemia aplastik, keganasan yang dapat mengakibatkan imunokompromis $^{3}$, atau terdapat riwayat trauma sebelumnya. ${ }^{9}$ Pada pasien ini terdapat riwayat trauma pada dahi merupakan faktor predisposisi timbulnya Pott's puffy tumor.

Keluhan utama pasien berupa bengkak pada kelopak mata yang sudah pecah dan mengeluarkan nanah dari lubang di atas kelopak mata kiri. Menurut Akiyama et al (2012), ${ }^{3}$ gejala khas PPT adalah bengkak pada kening dan kelopak mata. Timbulnya fistula sinokutan juga merupakan salah satu gejala yang merupakan komplikasi dari Pott's puffy tumor. ${ }^{10}$

Diagnosis banding pada kasus ini adalah selulitis pada regio orbita. Menurut Bellaney yang dikutip oleh Tatsumi et al (2016), ${ }^{11}$ Diagnosis banding untuk Pott's puffy tumor dapat berupa hematoma, infeksi pada kulit dan jaringan lunak dan tumor pada jaringan lunak.
Pemeriksaan penunjang yang dilakukan adalah CT Scan sinus paranasal. Pemeriksaan CT dengan kontras merupakan modalitas imaging yang paling efektif karena bisa menilai tulang dan jaringan lunak. 4,6 Akan tetapi, pada pasien remaja dan anak-anak lebih baik menggunakan modalitas MRI karena dapat mengurangi paparan radiasi. ${ }^{3,12}$

Tindakan pembedahan untuk rinosinusitis kronis pada kasus ini adalah dengan BSEF dan drainase sinus perkutaneus. Menurut Sharma et al (2017) $)^{1}$ dan Akiyama et al $(2012)^{3}$, tindakan invasif minimal ini menjadi pilihan pertama bila inflamasi terlokalisir pada area yang kecil dan tidak terdapat komplikasi.

Penatalaksanaan sinusitis frontal dengan Pott's puffy tumor pada pasien ini adalah dengan drainase endonasal sinus frontal Draf II tipe Ila yang dikombinasikan dengan pendekatan eksterna. Menurut Draf (2016), Draf II tipe Ila diindikasikan pada sinusitis frontal dengan komplikasi serius. ${ }^{8}$ Kombinasi dengan pendekatan eksterna diindikasikan bila terdapat nekrosis dan terbentuk fistula. ${ }^{8}$

\section{SIMPULAN}

Penatalaksanaan Pott's puffy tumor memerlukan kombinasi antara pemberian antibiotik dan tindakan pembedahan. Antibiotik yang diberikan dapat berupa antibiotik spektrum luas. Tindakan pembedahan bertujuan untuk drainase sinus frontal dan membersihkan jaringan dan tulang yang terinfeksi

\section{DAFTAR PUSTAKA}

1. Sharma P, Sharma S, Gupta N, Kochar P, Kumar Y. Pott puffy tumor. Oto-Rhino-Laryngologia. 2017;5(6):287-9.

2. Peric A, Milojevic M, Ivetic D. A Pott's Puffy Tumor Associated with Epidural-Cutaneous Fistula and Epidural Abscess: Case Report. Balkan Med J. 2017;34(3):284-7.

3. Akiyama K, Karaki M, Mori N. Evaluation of adult pott's puffy tumor: Our five cases and 27 literature cases. Laryngoscope. 2012; 12(11): 2382-8.

4. Orlandi RR. Pott's puffy tumor. Dalam: Kountakis S. Senior B. Draf W, editor (penyunting). Frontal 
sinus. Edisi ke-2. New York: Springer; 2016. hlm.203-8.

5. Leung RM, Walsh WE, Kern RC. Sinonasal Anatomy and Physiology. Dalam: Johnson JT, Rosen CA, editor (penyunting). Bailey's Head and Neck Surgery otolaryngology. Edisi ke-5. New York: Lippincott Williams \& Wilkins; 2014. hlm.359-70.

6. Suwan PT, Mogal S, Chaudhary S. Pott's Puffy tumor: an uncommon clinical entity. Case Rep Pediatr. 2012;2012:1-4.

7. Cardenas E, Kaen A, Alobid I, Bernal-Sprekelsen M. Frontal sinus and Draf approach. Dalam: Bernal-Sprekelsen M, Alobid I, editor (penyunting). Endoscopic approaches to the paranasal sinus and skull base. Stuttgart: Thieme; 2017.hlm.37-48

8. Draf W. Endonasal frontal sinus drainage type IIII according to Draf. Dalam: Kountakis S. Senior
B. Draf W. Frontal Sinus. Edisi ke-2. New York: Springer; 2016. p.219-30.

9. Salomão JF, Cervante TP, Bellas AR, Boechat MCB, Pone SM, Pone MVS, et al. Neurosurgical implications of Pott's puffy tumor in children and adolescents. Child's Nerv Syst. 2014;30(9):152734.

10. Goldfarb A, Hocwald E, Gross M, Eliashar R. Frontal sinus cutaneous fistula: a complication of Pott's puffy tumor. Otolaryngol - Head Neck Surg. 2004;130(4):490-1.

11. Tatsumi S, Ri M, Higashi N, Wakayama N, Matsune S, Tosa M. Pott's Puffy Tumor in an adult: a case report and review of literature. $J$ Nippon Med Sch. 2016;83(5):211-4.

12. Bhalla $\mathrm{V}$, Khan $\mathrm{N}$, Isles $\mathrm{M}$. Pott's puffy tumour: the usefulness of MRI in complicated sinusitis. J Surg Case Reports. 2016;3:1-3. 